of those medical officers who are responsible for the remaining 3200 men and women lodgers in the other Salvation Army shelters of London.-I am, Sirs, yours truly,

F. J. Waldo, M. A., M.D. Cantab, D.P.H., Medical Otficer of Health, St. George, Southwark. Plowden-buildings, Temple, E.C., June 7th, 1893.

\section{"THE TESTS OF DEATH."}

\section{To the Editors of THE LANCET.}

SIRS, - About, a year ago a leading article appeared in the Daily Telegraph in which the writer strongly urged upon the Government the adoption of a law compelling sepulture within twenty-four hours of supposed death. I wrote to the editor calling his attention to the fact that putrefaction was the only certain sign of death and pointed out that the English system of delay for a few days was the only one by which we could be guaranteed against the occurrence of such frightful mistakes as are from time to time recorded by the Paris correspondent of the same journal. My letter was not inserted, but I think you will agree with me that Dr. Haward's case fully bears out my contention. It may interest your readers to learn that there are two tests which, it appears, were not adopted by Sir Benjamin Ward Richardson in the case in question. The first of these is the application of leeches which, it is asserted, cannot draw blood from a dead body, and the second the formation of a blister by heat, which will contain air only if life is extinct and serum if the vital functions are merely suspended. I am, Sirs, yours faithfully,

Nottingham, June 12th, 1893. Chas. Bell TAYlor, M.D.

\section{To the Editors of THE LANCET.}

SIRS,--In the report by Dr. E. Haward of nine tests one other is not mentioned which has apparently been of useviz, the tying a thin string or thread round the root of the nail of one or more fingers. If life is still present the blue discolouration of impeded circulation is soon apparent; if life is over the wax. like colour of the digit remains. I should be glad to know if this test has failed.

June 12th, 1893. I am, Sirs, yours faithfully,

\section{THYMOL AS AN ANTHELMINTIC IN FILARIASIS.}

\section{To the Editors of THE LANCET.}

Sins, - Surgeon-Lieutenant-Colonel E. Lawrie, in ThE LANCET of Feb. 14tb, 189l, and Nov. 26th, 1892, having stated his belief in the efficacy of thymol as an anthelmintic in cases of filaria sanguinis hominis, and founding that belief on the experience of two cases in which cure was the result, I was induced to give that remedy a full and fair trial in the case of a patient suffering from chyluria who came under my observation in the autumn of last zear, and in whose blood the filaria nocturna abounded. My patient began on Dec. 3rd, 1892. to take three grains of the drug in the day, on the 26th it was increased to six grains a day, on Jan. 20th, 1893, to nine grains a day, on Feb. 5th to twelve grains a day, and on Feb. 20th to fifteen grains a day, and this dose was continued till May $12 \mathrm{th}$, a period of twenty-four weeks, and was then discontinued. It did not affect in any way the health or comfort of the patient, except that the chyluria was greatly improved. On examining the blood the parasites were observed to be not quite so abundant, but just as active as before the treament was commenced ; apparently they were in nowise affected by the long course of thymol. The result of this treatment accords with that of Dr. Manson, who believes that the "attempt to cure filarial chyluria by the administration of a parasiticide is founded on a misconception of the true pathology of this disease and of the part played by the filariæ in its production"-although chyluria may be greatly benefited and apparently cured by the action of the drug-and that such benefit would be derived from its balsamic properties, which would have an influence on any cystitis connected with chyluria, as well as a topical toxic influence on the lymphatics of the urinary tract, in the same way that copaiba, cubebs \&c. might have.-I am, Sirs, yours truly,

CHARLES WJTIIAMS,

Senior Surgeon Norfolk and Norwich Hospital.

\section{AFRICAN HAMOGLOBINURIC FEVER. To the Editors of THE LANCET.}

Sins, - In the paper on the above subject read by Dr. Patrick Manson before the Epidemiological Society ${ }^{1}$ he states that it is "practically confined to tropical Africa (especially the west coast) and America," and that "there was no accurate or authentic record of a single case in or amongst persons returning from any part of Asia." It is, however, fairly common in Assam and, I believe, other malarious parts of India, and is well known to old planters as "jungle fever." In a European community averaging about twenty only. I have myself seen eight cases, five of them fatal, since 1878, and one of those who recovered died some two years afterwards in another district of the same disease. Two men now here tell me they suffered from it in the Duars district of Bengal. Dr. Manson states that it rarely attacks Europeans in Africa during their first year. From my limited experience this rule seems to apply here also. One case (the mildest $I$ have seen) was in a man in his second year of residence, three occurred in the fourth year of residence (with two recoveries), and the other patients had been out eight years or more and all of them succumbed; three, however, were only from four to seven months back from leave to England, which looks as if they had lost their protective acclimatisation by the trip home. As Dr. Manson says, it is frequent in tropical America, and it is certainly not uncommon in India--why, then, call it "African"? If any prefix be necessary would not "tropical " be more accurate? Do the natives of the West Coast of Africa suffer from it? I am in medical charge of some thousands of natives-men, women and children-on the tea estates here, but have never seen a case amongst them, though they suffer from fever, enlarged spleen and other effects of malarial poisoning more than Europeans.-I am, Sirs, yours faithfully,

Meesa, Assam, May 19th, 1893.

J. B. RUDDUCK, L.R.C.P. Lond.

\section{“DEATH UNDER CHLOROFORM."}

\section{To the Editors of THE LANCET.}

Sirs,-In The LanceT of June 10th Mr. Foy draws attention to two cases in which fatal syncope occurred on the operating table without the use of any anæsthetic, and he thinks this important at a time "when every death under chloroformisation is ascribed to the anæsthetic." The latter statement is to me quite astounding, as it is notorious that many deaths under chloroform are ascribed to anything rather than to the use of the anæsthetic. Thus in a recent case reported in the Nencastle Chronicle of the 27 th ult. it is stated that the patient was "about to be carried back to the ward, when he fainted and died." (The necropsy showed flabby state of the heart \&c.) He died "from failure of the heart, but that was not due to the chloroform. There was a very much smaller quantity of chloroform used than is customary, and he was under it a very short time." A similar case happened recently in this city in which the operator attributed death to the strain of vomiting acting on a fatty heart. Such cases could be multiplied indefinitely. It was a favourite argument of Sir James Simpson that death might frequently be due to some other cause than the chloroform and apparently Mr. Foy leaves us to draw the same inference. It appears to me that this can apply to only a very small number of cases and that the London committee of 1864 showed a much better appreciation of the facts. They stated :" "Many of the deaths happened during trivial operations which, without chloro. form, are not attended with risk to life," Again, p. 371, speaking of two cases of fatty degeneration of the heart, they say that this may have contributed to the fatal result, but did not alone cause it. With regard to mental emotion, they state that this should be looked upon as a subordinate, not as the principal, occasion of death. If these conclusions were well founded in 1864, it appears to me that the weight of evidence in their favour at the present day is quite overwhelming. I am, Sirs, yours truly,

Partick, Glasgow, June 12th, $1893 . \quad$ ROBERT KIRK, M.D. xlvii., p. 339 . 